\title{
M/V “Tokei Maru”: Would the Actions of her Brave Master Consist General Average?
}

\author{
Dr Ioannis Voudouris \\ Assistant Professor, Department of Law \\ School of Business and Law, Frederick University. \\ Dr Nicholas G. Berketis \\ Visiting Lecturer, Department \\ Maritime Transport and Commerce \\ School of Business and Law, Frederick University.
}

\begin{abstract}
On Saturday, 9th September, 1922, the Turkish army entered Smyrna, the richest and most cosmopolitan city in the Ottoman Empire. The city's vast wealth created centuries earlier by powerful dynasties, its factories teemed with Greeks, Armenians, Turks, and Jews. Together, they had created - a predominantly Christian and Greek city - that was unique in the greater Islamic world. But to the majority of Turkish nationalists, Smyrna and its Christian population was a city of infidels that should be ethnically and religiously cleansed. At Smyrna, the Japanese had been the only country to send ships to rescue refugees from the slaughter. Purpose of this article is to examine the marine insurance aspects of the story relating to the "TOKEI MARU", a Japanese steamship, and her brave captain who, by emptying her cargo holds, rescued more than 800 people and brought them to safety at the port of Piraeus. The authors examine the jettisoning of above vessel's cargo in exchange for saving Greek refugees in light of the General Average principle.
\end{abstract}

\section{GENERAL AVERAGE}

The "General Average", as part of the law of necessity, recognises that the risk of loss of a ship and her cargo (as a whole) is apparently and reasonably greater than the significantly smaller expenditure (damage) suffered among the participants of the maritime adventure. It consists of a voluntary sacrifice of property made, or extraordinary expenditure incurred, in a time of peril threatening the whole property involved in a common maritime adventure, with a view to preserving it from that peril, and embodies the principle that when such a sacrifice has been made, or expenditure incurred, the whole property preserved shall contribute to the loss sustained, or the expenditure incurred, as the case may be.

The doctrine of General Average has deep historic origins. It formed part of the Rhodian Law, and was in existence centuries before marine insurance was known at all. The Rhodians were originally an agricultural people, but early in their history turned to commerce in order to dispose of their surplus products. They were harassed by their neighbours, who continually waged war upon them, 
but by $916 \mathrm{BC}$, they had obtained the mastery of the sea. At about this time they promulgated a system of maritime jurisprudence, which became the basis of the Athenian and Roman, Byzantine code, that also transferred to the Arabs and then into and of all modern laws relating to commerce and navigation. No reference to insurance is found in this system, but General Average is recognised as a commercial custom.

\section{Example}

Value of cargo thrown overboard: 10,000

- Boat worth 100,000 pays $\rightarrow 8,334$

- Merchant $1-10,000$ pays $\rightarrow 833$

- Merchant $2-10,000$ pays $\rightarrow 833$

- Merchant 3 receives $\leftarrow 10,000$

It was customary in the early days for merchants to travel with their wares and there might be in the same ship several merchants, each journeying with his / her goods in order to sell them at the port of destination and therefore buy other goods with the proceeds. During the course of the voyage let it be supposed that a severe storm arises threatening the safety of the ship and making necessary the casting overboard of part of the cargo in order to lighten the vessel. Naturally, a dispute ensues as to whose goods shall be sacrificed, each merchant preferring that his / her neighbour's goods and not his own be cast out. There is, however, little tune for argument when a ship is labouring in a storm and, in order both to prevent such disputes and to effect the saving of vessels and their cargoes without having all the loss fall on any one or two individuals whose cargo could most easily be jettisoned, the custom arose of having each person interested in the venture, whether shipowner or cargo owner, contribute to make good the loss suffered by those whose property was sacrificed. This custom soon obtained the force of law and is now part of the commercial code of all maritime nations. The word average, as used in marine insurance, means loss or damage, so that a General Average is a loss falling generally on all the interests involved in a maritime venture as distinguished from Particular Average or a loss falling on one particular interest.

There have been many legal definitions of general average, but probably the one most often quoted is that is Lawrence J. in Birkley v. Presgrav:

"All loss which arises in consequence of extraordinary sacrifices made or expenses incurred for the preservation of the ship and cargo comes within general average, and must be borne proportionately by all who are interested".

The Marine Insurance Act, 1906, embodies the following definition of general average, viz.:

1. A general average loss is a loss caused by or directly consequential on a general average act. It includes a general average expenditure as well as a general average sacrifice.

2. There is a general average act where any extraordinary sacrifice or expenditure is voluntarily and reasonably made or incurred in time of peril for the purpose of preserving the property imperilled in the common adventure.

3. Where there is a general average loss, the party on whom it falls is entitled, subject to the conditions imposed by maritime law, to a rateable contribution from the other parties interested, and such contribution is called a general average contribution. 
Voudouris, I., \& Berketis, N. G. (2020) M/V “Tokei Maru”: Would the Actions of her Brave Master Consist General Average? Archives of Business Research, 8(5). 298-301.

The losses which give rise to general average contribution come, as above stated, under two heads:

1. Sacrifices of property;

2. Expenditure.

But before proceeding to consider these subjects, it will be well to emphasise the essential features which must be present in order to give rise to general average contribution.

First of all, the common adventure must be in peril. The peril must be real and not imaginary, and it must be imminent, that is to say it must be "substantial and threatening, and something more than the ordinary perils of the sea". ${ }^{2}$ The fear of the possibility of encountering a peril is not sufficient to give rise to a claim for general average contribution, nor is a mistaken idea that a peril exists when in fact it does not.

In the case of Société Nouvelle d'Armement vs Spillers \& Bakers, Ltd. ${ }^{3}$ an action was brought by the owners of a sailing vessel to recover from the charterers, who were the owners of the cargo, a contribution towards the cost of hiring a tug to tow the vessel from Queenstown to Sharpness, owing to the presence of enemy submarines in that neighbourhood. It was claimed by the owners of the vessel that the sum paid for the hire of the tug was a general average expense. The claim failed on the ground that, though the action of the master in engaging the tug probably minimized the risk of the vessel being attacked by submarines, owing to her increased speed, there was no evidence that the vessel and her cargo were exposed to any extra and abnormal peril.

\section{Seaworthiness}

While the printed and written form of policy sets forth the terms of the contract between the Assured and the Underwriter, this agreement is subject to "implied warranties". These implied warranties are agreements not embodied in the terms of the Policy, but read into it by law. That is, the parties to the contract agree by implication when making the insurance, that certain conditions exist and that certain well-defined rules will be followed in the conduct of the voyage. These implied warranties are the result of law court decisions of the preceding centuries with respect to marine insurance policies, decisions which are, in many cases, merely the embodiment, in legal form, of the customs and usages of merchants, and become just as binding on the Assured and on the Underwriter as are conditions definitely expressed in the body of the Policy.

The most important of the implied warranties is that of seaworthiness. In order that this implied warranty may be complied with, it is necessary that the vessel, at the commencement of the voyage (or of any separate part of the voyage, if divisible) be suitably constructed and equipped, properly officered and manned, and sufficiently fuelled and provisioned, for the carrying of the specified cargo insured on the particular voyage described.

In this respect and as the M/V "TOKEI MARU" was not a passenger ship, by carrying passengers without the consent of her Underwriters - even during an extreme situation, breached the implied warranty of seaworthiness

\section{Sources}

1. Benedict R., (1909), "The Historical Position of the Rhodian Law", The Yale Law Journal, Vol. 18, No. 4, pp. 223 242. 
2. Bennet H., (2006), "Law of Marine Insurance", $2^{\text {nd }}$ edition, Oxford University Press.

3. Gilman J., Merkin T., Cooke J., Hopkins P., Templeman M., (2008), "Arnould's Law of Marine Insurance and Average", 17th Edition, Sweet \& Maxwell, London.

4. Goodacre, J., Kenneth, (1981), "Marine Insurance Claims", 2 ${ }^{\text {nd }}$ Edition, Witherby \& Co. Ltd., London.

5. Hodges S. (1999), "Cases and Materials on Marine Insurance Law", Cavendish, London \& Sydney.

6. Khalilieh H., (2006), "Admiralty and Maritime Laws in the Mediterranean Sea (ca. 800-1050). The Kitab Akriyat al-Sufun vis-à-vis the Nomos Rhodion Nautikos", Brill, Leiden \& Boston.

7. Llewellyn Smith M., (1998), "Ionian Vision Greece in Asia Minor 1919-1922", C. Hurst \& Co. (Publishers) Ltd.

8. Murata - Sawayanagi, Nanako, (2017), "The Memory in a Crisis: A Japanese Ship Helping Out Greek Refugees on the Quay of Smyrna in 1922", Mediterranean World, 23: 135-146.

9. Templeman, Frederick, Greenacre, C.T., (1948), "Marine Insurance: Its Principles \& Practice", Macdonald \& Evans, London.

10. Winter, D., William, (1929), "Marine Insurance. Its Principles and Practice", McGraw-Hill Book Company, Inc., NY \& London.

11. The National Herald, "A Captain Remembers September 1922" <www.thenationalherald.com/186540/tokeimaru-japanese-ship-smyrna-september-1922>

\section{References}

1. Birkley vs Presgrave [1801] 1 East 220.

2. Per Sankey J. in Société Nouvelle d'Armement vs Spillers and Bakers Ltd [1917] 1 KB 865; 22 Com. Cas. 211; 14 Asp. M.L.C. 16; 33 T.L.R. 189.

3. Supra 